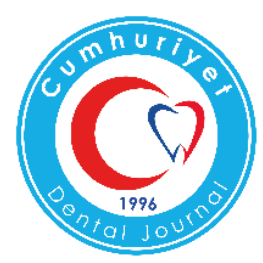

\section{RELATIONSHIP OF FOREHEAD AESTHETICS WITH FRONTAL SINUS SIZE} AND SKELETAL MALOCCLUSIONS

\section{ABSTRACT}

Objectives: Forehead inclination and aesthetics have received very limited attention, although forehead is critically important in obtaining total facial aesthetics. The aim of this study was to evaluate the relationship between frontal sinus fields, forehead morphology and skeletal malocclusion.

Materials and Methods: A total of 224 extraoral lateral photographs and cephalometric radiographs from skeletal class I, class II and class III patients in post-pubertal period were investigated. Extraoral photographs and cephalometric radiographs were superimposed for each patient before measurements. The photographs were evaluated in three groups: Group A: Skeletal Class I malocclusions $(\mathrm{n}=85)$, Group B: Skeletal Class II malocclusions ( $\mathrm{n}=74)$, Group C: Skeletal Class III malocclusions ( $\mathrm{n}=65)$. All subjects from the three groups were classified according to the types of the foreheads, and then on the photographs, four different angle measurements (A1, A2, A3, A4) were performed. In addition, the frontal sinus (FS) fields were calculated using the RadiAnt Dicom Viewer (Beta version) on cephalometric and posterior-anterior radiographs. One-way ANOVA, Chisquare, and Student $\mathrm{t}$ tests were used for statistical evaluation.

Results: No significant relationships between the skeletal malocclusions and the forehead types were seen. In Group C, the FS fields and A2 angles were higher than in the other groups. No gender-related variations were detected for any measurements.

Conclusions: There was a limited correlation between malocclusions, frontal sinus and forehead morphology. Gender was not an element that creates morphological differences in forehead aesthetics.

Keywords: Forehead aesthetics, frontal sinus, skeletal malocclusions.

\section{Hasan Camc1 ${ }^{1}$}

ORCID IDs of the authors:

H.C. $\quad 0000-0003-0824-4192$

\footnotetext{
${ }^{1}$ Afyonkarahisar Health Science University, Department of Orthodontics, Afyonkarahisar, Turkey.
} 


\section{INTRODUCTION}

One of the most important element of orthodontic diagnosis and treatment planning is soft tissue analysis. ${ }^{1}$ Numerous measurement techniques have been developed on lateral cephalometric radiographs for the comparison of initial and final results. ${ }^{2,3}$ In the assessment of facial aesthetics, the focus is generally on the lower two-thirds of the face. The forehead has an important role in facial aesthetics and is located in the first third of the face. However, orthodontists may not focus enough to forehead inclination and morphology when evaluating facial aesthetics. Forehead silhouette is a simple curvature reflecting frontal bone morphology and seen straight, round or angular depending on anatomic structure of the frontal bone. Age-dependent morphological changes occur in facial soft tissue. ${ }^{4,5}$ Frontal region is one of these affected areas. Someone with an round forehead subconsciously gives a message that the person is young. Foreheads have an round structure in the first years of life but this curvature becomes straight with age. ${ }^{6}$ As an round forehead creates a younger appearance, this is frequently demanded especially by women. ${ }^{7}$

In examination of skeletal class II malocclusions lower third of the face is frequently focal point, whereas in class III cases the focus is the midface region. ${ }^{8}{ }^{8}$ However, facial aesthetics should be considered with all the three parts. It is for the benefit of proper facial reconstruction for those with facial anomaly, syndromic patient, terrible accident, etc. ${ }^{10-12}$

\section{Growth and Development of the Frontal Sinuses}

Frontal sinus (FS) is located in the anterior part of the cranial bone and surrounded by two thick cortical bones. Its development begins at the 4 th or 5th week of intrauterine life. In the postnatal period, the development continues until puberty or even early adulthood. ${ }^{13}$ The first frontal pneumatization of the bone begins gradually at age around one. When the infant is 2 years of age, secondary pneumatization begins. FS continues to grow from 2 years until adolescence and reaches the final capacity in pneumatization. ${ }^{14}$ Only, it may start appearing on the computer tomography (CT) after the age of 3 . The suture between the two bones becomes ossified during infant growth, and the FS is divided into two as of right and left. Right and left FS could develop asymmetrically and independently, and one side may not develop at all. In one study, the right and left FSs were shown to be between $3 \%$ and $5 \%$ aplastic. ${ }^{13}$ Factors affecting this abnormal development of the FS include factors such as race, geography, and climate. ${ }^{15,16}$

The anatomical structure of the FS is unique to each individual in terms of size and shape. Therefore, It can be used as a biomarker for the identification of individuals, such as fingerprints. ${ }^{17}$ Growth and development of the FS are linked to other neighboring cranial structures. For instance, Aslier et al. reported a positive correlation between FS and maximum cranial length and nasal height. ${ }^{18}$ Similarly, the FS could affect the frontal slope and surrounding morphology.

The aim of this research was to investigate the relationship between the FS and skeletal malocclusions, and also to analyze its effect on the forehead morphology and types. We therefore hope to help maxillofacial or plastic surgeons achieve better results in facial reconstruction.

\section{MATERIALS AND METHODS Experimental Groups}

This research was approved by Clinical Research Ethics Committee of Afyonkarahisar Health Science University (ID:2019-224). In the power analysis to determine sample size, it revealed that at least 65 patients were required for each group in order to obtain sufficient statistical power $(\mathrm{n}>37$, $\alpha=0.05$, and $1-\beta=0.80$ ). Informed consent forms were obtained from all the patients included in the study. Hand-wrist radiographs were evaluated during the selection of the samples and only patients in the MP3 and Ru phases were included. Two hundred twenty four patients in post pubertal period (43 male with mean age $17 \pm 2$ and 181 female with mean age $16 \pm 2$ ) were divided into three groups based on cepholometric analysis (ANB angle). Group A: Skeletal Class I malocclusions ( $\mathrm{n}=85)$, Group B: Skeletal Class II malocclusions ( $\mathrm{n}=74)$, Group C: Skeletal Class III malocclusions $(n=65)$. Patients with the following characteristics were not included in the study: a history of previous orthodontic treatment, mouth 
breathing, maxillary transverse deficiency due to mouth breathing, and sinusitis complaints.

\section{Profile Photo And Cephalometric Radiograph Evaluation}

Lateral cephalometric radiographs were taken using Planmeca Promax device from all the patients with their true horizontal plane parallel to the ground. Extraoral profile photos were taken by using a Canon 60D-EOS camera with a Sigma $105 \mathrm{~mm} \mathrm{f} / 28$ EX DG macro lens placed on a tripod $1.5 \mathrm{~m}$ away from the patients. Particular attention was paid to the foreheads for being bare when taking the profile photos. According to the photographs, the foreheads were categorized as straight, round or angular (Figure 1).

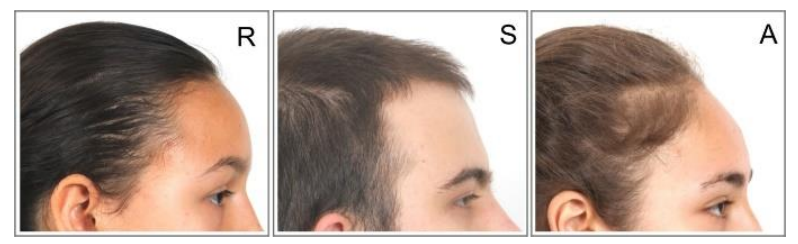

Figure 1 Types of Forehead. R: Round, S: Straight, A: Angular

The points identified by Andrew (Trichion, glabella, superion, FFA point) were taken as reference for forehead measurements ${ }^{19}$ (Figure 2).

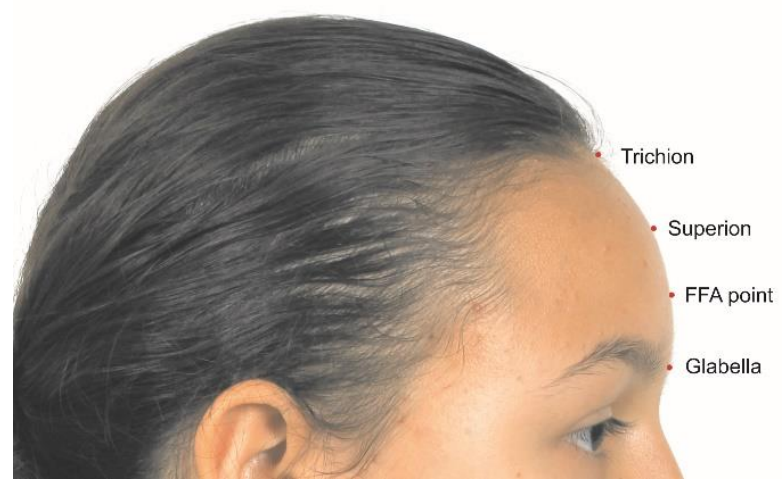

Figure 2 Anatomical landmarks on the forehead

The definitions of these landmarks are as follows ${ }^{20}$; Trichion (T): the most superior aspect of the forehead on the hairline in individuals with a relatively straight forehead, Glabella (G): The most inferior aspect of the forehead, Superion (S): Most superior aspect of the forehead when the forehead is either rounded or angular in contour, FFA point: Midpoint between trichion and glabella for straight foreheads or the midpoint between superion and glabella for rounded or angular foreheads. Before measurements, the lateral cephalometric film and the profile photo were superimposed to determine soft tissue landmarks properly by using
AudaxCeph Version 5.X orthodontic software for each patient (Figure 3).

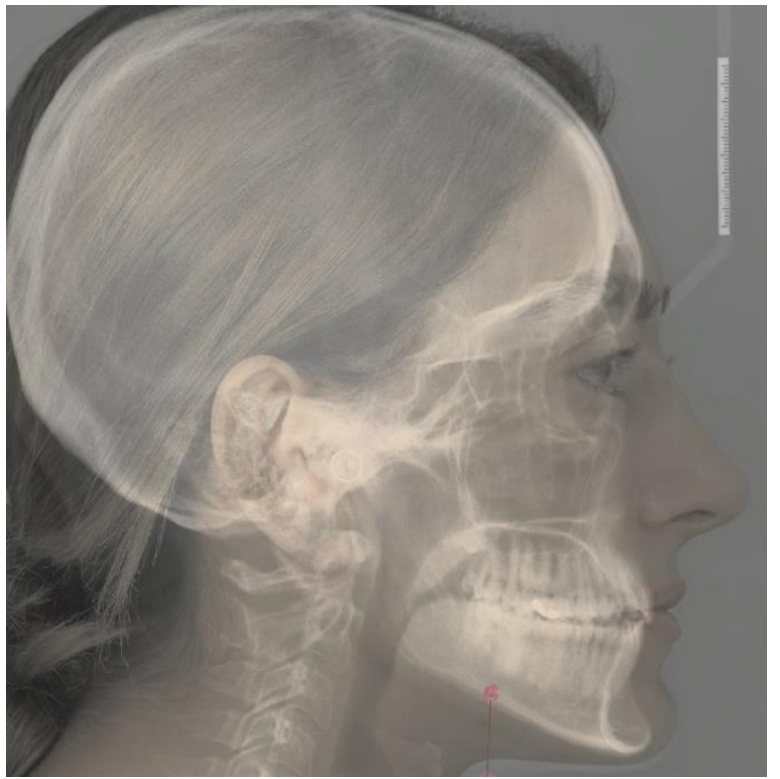

Figure 3 Superimposition of lateral photograph and lateral cephalometric radiograph

By taking into consideration Andrew's anatomical landmarks and true horizontal $(\mathrm{TH})$ plane, one angular measurement for straight foreheads and four angular measurements for round or angular foreheads were performed (Figure 4-5).

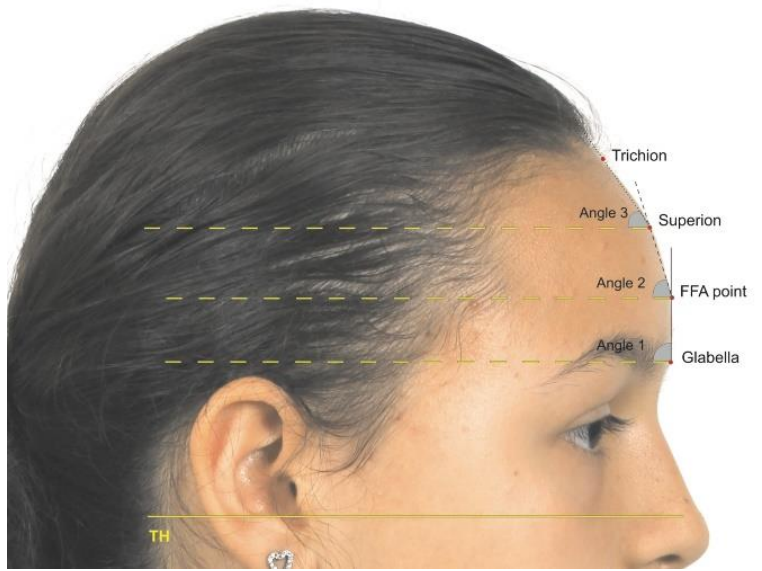

Figure 4 Schematic view of Angle 1 (TH/G-FFA), Angle 2 (TH/FFAS), Angle 3 (TH/S-T)

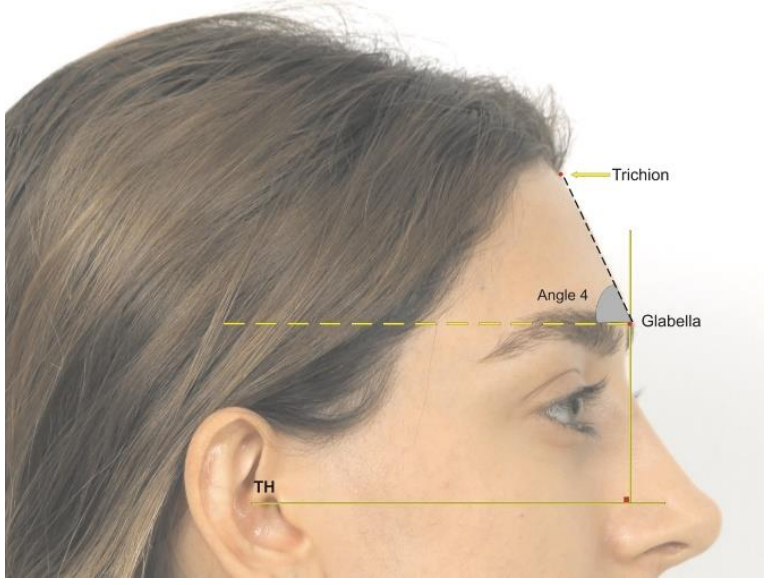


Figure 5 Schematic view of Angle 4 (TH/G-T line)

Angle 1 (A1) : Between TH and G-FFA line, Angle 2 (A2): Between TH and FFA-S line, Angle 3(A3): Between TH and S-T line, Angle 4 (A4): Between $\mathrm{TH}$ and G-T line ${ }^{21}$. Cephalometric analysis were performed by the same experienced researcher (H.C.)

\section{Calculation of the Frontal Sinus Fields}

The frontal sinus fields of all patients were calculated on both lateral cephalometric $\left(\mathrm{CEP} \mathrm{cm}{ }^{2}\right)$ and posterior-anterior $\left(\mathrm{PA} \mathrm{cm}^{2}\right)$ radiographs. For the fields calculation on the radiographs, RadiAnt Dicom Viewer (Beta version) was used. The radiographs were imported into the software in DICOM format. The fields on both CEP and PA radiographs were calculated with the software's 'Closed Polygon' option after the calibration (Figure 6). Patients with aplastic sinus or uncertain sinus borders were excluded from the study.

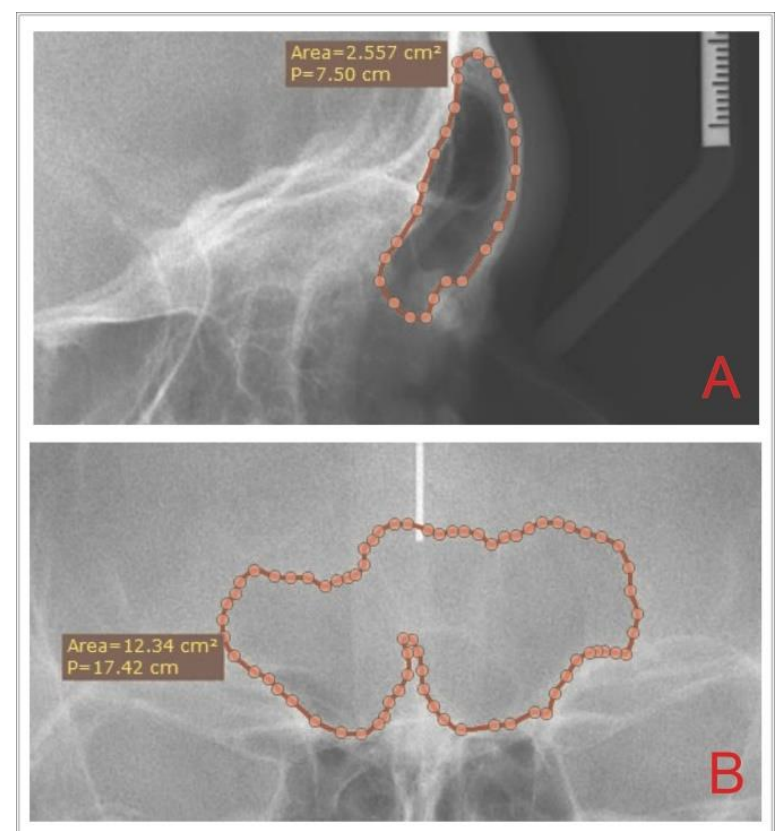

Figure 6: Calculation of FS fields. A: Cephalometric radiograph, B: Posterior-anterior radiograph.

\section{Statistical Analysis}

All statistical tests were done by SPSS 22.0 package program (SPSS Inc, Chicago, III). Oneway analysis of variance models (ANOVA) and Tukey post hoc test was used to compare the measurements between the three groups. Independent T-test were performed to compare the measurements by gender. The homogeneity of the distribution of forehead types in the malocclusion groups was evaluated by Chi-square test. The level of significance was determined as $\mathrm{P}<0.05$. In ten randomly selected patients, all parameters were reperformed one month later by the same experienced researcher. The intraexaminer variability was tested using these dual measurements via Pearson correlation test (Table 1).

Table 1 Pearson test results, ${ }^{*} \mathrm{P}<0.01$

\begin{tabular}{lllllll}
\hline Measurements & A1 & A2 & A3 & A4 & CEPcm ${ }^{2}$ & PAcm $^{2}$ \\
\hline Correlation coefficient & $0.998^{*}$ & $0.996^{*}$ & $0.997^{*}$ & $0.950^{*}$ & $0.976^{*}$ & $0.903^{*}$ \\
\hline
\end{tabular}

A1: Angle 1, A2: Angle 2, A3: Angle 3, A4: Angle 4, CEP cm2: lateral cephalometric area, PA cm2: posterior-anterior area

\section{RESULTS}

In Group C, both the CEP and PA fields of the FS were higher than the other groups. However, a statistically significant difference was only between Group C and Group A. Similarly, the A2 measurement was the highest in Group $\mathrm{C}$, and only a significant difference between Group $\mathrm{A}$ and Group C was seen (Table 2). 
Table 2 Comparison of measurements by malocclusion groups, ${ }^{*} \mathrm{P}<0.05$

\begin{tabular}{lcccccc}
\hline Measurements & $\begin{array}{c}\text { A1 } \\
\text { Mean } \pm \text { SDs }\end{array}$ & $\begin{array}{c}\text { A2 } \\
\text { Mean } \pm \text { SDs }\end{array}$ & $\begin{array}{c}\text { A3 } \\
\text { Mean } \pm \text { SDs }\end{array}$ & $\begin{array}{c}\text { A4 } \\
\text { Mean } \pm \text { SDs }\end{array}$ & $\begin{array}{c}\text { CEPcm }^{2} \\
\text { Mean } \pm \text { SDs }\end{array}$ & $\begin{array}{c}\text { PAcm }^{2} \\
\text { Mean } \pm S D s\end{array}$ \\
\hline Group A & $80.1 \pm 4.6^{\mathrm{a}}$ & $76.2 \pm 5.0^{\mathrm{a}}$ & $58.4 \pm 5.0^{\mathrm{a}}$ & $71.8 \pm 5.2^{\mathrm{a}}$ & $1.99 \pm 0.8^{\mathrm{a}}$ & $8.46 \pm 3.57^{\mathrm{a}}$ \\
Group B & $80.9 \pm 5.7^{\mathrm{a}}$ & $76.4 \pm 4.8^{\mathrm{ab}}$ & $58.8 \pm 5.7^{\mathrm{a}}$ & $73.1 \pm 6.0^{\mathrm{a}}$ & $2.11 \pm 0.8^{\mathrm{ab}}$ & $8.49 \pm 3.20^{\mathrm{ab}}$ \\
Group C & $108.0 \pm 136.0^{\mathrm{a}}$ & $79.0 \pm 4.1^{\mathrm{b}}$ & $60.2 \pm 4.8^{\mathrm{a}}$ & $83.7 \pm 77.1^{\mathrm{a}}$ & $2.46 \pm 0.9^{\mathrm{b}}$ & $9.83 \pm 3.24^{\mathrm{b}}$ \\
\hline
\end{tabular}

In each column, different superscripts indicate statistically significant difference between groups (p<.05), SDs: Standard deviations, A1: Angle 1, A2: Angle 2, A3: Angle 3, A4: Angle 4, $\mathrm{CEP} \mathrm{cm}^{2}$ : lateral cephalometric area, $\mathrm{PA} \mathrm{cm}^{2}$ : posterior-anterior area

There was no difference between the groups in the other measurements $(P>0.05)$. Sinus fields of men in both CEP and PA were found to be bigger than females. However, that difference was not statistically significant (Table 3). And also no statistically significant difference between men and women was found in the angular measurements.

Table 3 Comparison of the measurements by gender.

\begin{tabular}{|c|c|c|c|c|c|}
\hline & Gender & $\mathrm{N}$ & Mean & Std. Deviation & Significance \\
\hline \multirow{2}{*}{$\mathrm{CEP} \mathrm{cm}^{2}$} & $\mathrm{~F}$ & 181 & 2.01 & .80 & Ns \\
\hline & M & 43 & 2.82 & .98 & \\
\hline \multirow{2}{*}{$\mathrm{PA} \mathrm{cm}^{2}$} & $\mathrm{~F}$ & 181 & 8.45 & 3.2 & Ns \\
\hline & $\mathrm{M}$ & 43 & 10.61 & 3.6 & \\
\hline \multirow{2}{*}{ A1 } & $\mathrm{F}$ & 109 & 87.89 & 70.4 & Ns \\
\hline & $\mathrm{M}$ & 4 & 77.77 & 6.0 & \\
\hline \multirow{2}{*}{ A2 } & $\mathrm{F}$ & 109 & 76.94 & 4.9 & Ns \\
\hline & $\mathrm{M}$ & 4 & 78.60 & 4.4 & \\
\hline \multirow{2}{*}{ A3 } & $\mathrm{F}$ & 109 & 59.13 & 5.1 & Ns \\
\hline & M & 4 & 56.10 & 5.0 & \\
\hline \multirow{2}{*}{ A4 } & $\mathrm{F}$ & 181 & 76.56 & 46.5 & Ns \\
\hline & M & 43 & 72.18 & 4.9 & \\
\hline
\end{tabular}

F:Female, M: Male, Ns: No significance, A1: Angle 1, A2: Angle 2, A3: Angle 3, A4: Angle 4, CEP cm2: lateral cephalometric area, PA cm2: posterior-anterior area

The relationship between forehead types and skeletal malocclusions was presented in Table 4. In comparison of the distribution of the forehead types for the each group, no correlation was found between the skeletal malocclusion and the forehead types.

Table 4: Evaluation of the relationship between the types of the forehead and the skeletal malocclusion. Chi-Square test results $\mathrm{P}>0.05$

\begin{tabular}{llcccr}
\hline & & \multicolumn{3}{c}{ Types of Foreheads } \\
\cline { 3 - 5 } & & Angular & Straight & Round & \\
\hline \multirow{2}{*}{ Group A } & Count & 19 & 34 & 32 & 85 \\
& Expected Count & 18.2 & 42.1 & 24.7 & 85.0 \\
\multirow{2}{*}{ Group B } & Count & 16 & 41 & 17 & 74 \\
& Expected Count & 15.9 & 36.7 & 21.5 & 74.0 \\
\multirow{2}{*}{ Group C } & Count & 13 & 36 & 16 & 65 \\
& Expected Count & 13.9 & 32.2 & 18.9 & 65.0 \\
\hline
\end{tabular}

Individuals with the same forehead types in all groups were compared with each other. In other words; class I, class II, class III patients with straight $(\mathrm{Cl} 1 \mathrm{~s}, \mathrm{Cl} 2 \mathrm{~s}$, $\mathrm{Cl} 3 \mathrm{~s})$ foreheads were compared among themselves, the patients with round foreheads (Cl1r, Cl2r, Cl3r) among themselves and individuals with angular foreheads (Cl1a, $\mathrm{Cl} 2 \mathrm{a}, \mathrm{Cl} 3 \mathrm{a})$ among themselves.
When the measurements of angular forehead type (Cl1a, Cl2a, and $\mathrm{Cl} 3 \mathrm{a}$ ) were compared for all values, no difference was found between groups $(\mathrm{P}>0.05)$. The comparison of straight foreheads (Cl1s, Cl2s, Cl3s) in terms of CEP, PA fields, and angle measurements did not state any significant difference. In the comparison of round foreheads (Cl1r, $\mathrm{Cl} 2 \mathrm{r}, \mathrm{Cl} 3 \mathrm{r}), \mathrm{Cl} 3 \mathrm{r}$ was observed to be 
significantly bigger than Cl1r only in terms of CEP

fields (Table 5).

Table 5: Comparison of round foreheads between the groups, *: $\mathrm{P}<0.05$

\begin{tabular}{lcccccc} 
Measurements & $\begin{array}{c}\mathrm{A} 1 \\
\text { Groups }\end{array}$ & $\begin{array}{c}\mathrm{A} 2 \\
\text { Mean } \pm \text { SDs }\end{array}$ & $\begin{array}{c}\text { Mean } \pm \text { SDs } \\
\text { Mean } \pm \text { SDs }\end{array}$ & $\begin{array}{c}\text { A4 } \\
\text { Mean } \pm \text { SDs }\end{array}$ & $\begin{array}{c}\text { CEPcm }^{2} \\
\text { Mean } \pm \text { SDs }\end{array}$ & $\begin{array}{c}\text { PAcm }^{2} \\
\text { Mean } \pm \text { SDs }\end{array}$ \\
\hline Cl1r & $81.0 \pm 4.2^{\mathrm{a}}$ & $76.1 \pm 4.9^{\mathrm{a}}$ & $59.8 \pm 5.0^{\mathrm{a}}$ & $71.7 \pm 4.1^{\mathrm{a}}$ & $1.6 \pm 0.7^{\mathrm{a}}$ & $6.9 \pm 3.2^{\mathrm{a}}$ \\
$\mathrm{Cl} 2 \mathrm{r}$ & $81.2 \pm 5.4^{\mathrm{a}}$ & $75.0 \pm 5.0^{\mathrm{a}}$ & $60.4 \pm 5.4^{\mathrm{a}}$ & $71.8 \pm 4.7^{\mathrm{a}}$ & $1.7 \pm 0.5^{\mathrm{a}}$ & $7.6 \pm 3.0^{\mathrm{a}}$ \\
$\mathrm{Cl} 3 \mathrm{r}$ & $129.5 \pm 182.8^{\mathrm{a}}$ & $78.4 \pm 4.1^{\mathrm{a}}$ & $61.6 \pm 5.1^{\mathrm{a}}$ & $113.7 \pm 155.0^{\mathrm{a}}$ & $2.23 \pm 0.8^{\mathrm{b}}$ & $7.5 \pm 1.7^{\mathrm{a}}$ \\
\hline
\end{tabular}

In each column, different superscripts indicate statistically significant difference between groups (p<.05), SDs: Standard deviations, A1: Angle 1, A2: Angle 2, A3: Angle 3, A4: Angle 4, CEP cm2: lateral cephalometric area, PA cm2: posterior-anterior area

\section{DISCUSSION}

The expectations and demands of humans from both dental aesthetic procedures and facial cosmetic surgery are increasing especially in the 21th century. ${ }^{22,23}$ This situation emphasizes the importance of evaluating facial aesthetics as a whole during orthodontics diagnosis and treatment. Though the forehead, which constitutes the upper $1 / 3$ of the face, is an important part of this whole, there are limited studies in the literature about forehead aesthetics. ${ }^{20,24}$

Malocclusions or types of anatomical structures might show different distribution between the genders because of sexual dimorphism. ${ }^{25-27} \mathrm{~A}$ female could perceive the same malocclusion or normal anatomical structure differently than a male because of the perception of aesthetics and attractiveness. ${ }^{28}$ In our study, no correlation was noted between gender and forehead slope or type. However; in terms of maximum patient satisfaction, extra attention is required to analyze the anatomical differences between the genders and the variability of aesthetic perceptions. Another factor that has impact on the aesthetic perception or anatomical structures change is age. For example; an older person's forehead has more inclination than a younger indiviual. ${ }^{29}$ Thus, male and female patients in post-pubetal period were included in the study.

Forehead slope and aesthetics could be evaluated with different measurement techniques. Hwang et al. evaluated forehead aesthetics by measuring an angle called FHA (forehead angle) on the cephalometric radiograph. ${ }^{20}$ This angle was located between the nasion perpendicular line (NP) and the line passing through the intersection point of the NP and forehead and the soft tissue of the glabella. However, this angle might vary depending on the morphology of the nasal bone. These evaluations in the anterior-posterior direction contain limited information about forehead aesthetics. In addition to this assessment in the sagittal direction, the forehead width (distance between lateral canthus) in the coronal view might be evaluated. Lee et al. have also studied forehead aesthetics by measuring forehead surface area or volume on 3D computed tomography (CT) images. ${ }^{30}$

Bad oral habits have negative side effects on dentofacial structures. ${ }^{31,32}$ These habits change the growth direction of anatomical structures. For instances; due to mouth breathing the face becomes long and narrow (adenoid face type or long face syndrome). ${ }^{33,34}$ Similarly, inadequate ventilation or chronic infection of the frontal sinus as an anatomical structure adjacent to the forehead, might affect the forehead inclination. Further studies are needed to determine whether this relationship exists. For these reasons, the patients with mouth breathing or chronic sinusitis were excluded from the study.

Forehead reflects the curvature of the frontal bone, but the soft tissue thickness that covers the bone surface is also a factor that might affect the aesthetic of the forehead. ${ }^{35}$ In the study of Kamak et al., soft tissue thickness differences among skeletal malocclusions were observed. ${ }^{36}$ Additionally, Hwang et al. ${ }^{37}$ reported that gender plays a role in soft tissue thickness. Therefore the thickness of soft tissue could be a factor that influences the findings.

The norm values of cephalometric measurements, soft tissue analysis or aesthetic 
criterias show racial differences. ${ }^{38,39}$ There might be different aesthetic expectations might be seen in each nation. ${ }^{40,41}$ Therefore, with a limited study on a particular race, it is not possible to make a clear statement about the presence or absence of the relationship between the forehead slope, types and skeletal malocclusions.

The types of the skeletal malocclusions is closely related with the parameters located the lower and middle $1 / 3$ of the face. ${ }^{42,43}$ Similarly, in our study, a significant relationship was found between the types of malocclusions and the some parameters of forehead slope.

The frontal sinus (sphenoid, ethmoid, maxillary, and frontal) is one of the four paranasal sinuses in the head and is the only paranasal sinus absent at birth. These four sinus development periods are different from each other and vary by gender. ${ }^{44}$ Spaeth et al. evaluated paranasal sinuses using CT images in the patients aged 0 to 25 years. They reported that the development of FS was completed at the age of 18 in boys, 15-16 in girls, and the final sizes were higher for boys. ${ }^{16}$ However, in our study, no relation was found between gender and frontal sinus size. Racial and regional variations in which studies are conducted may be the explanation for this. The sinus assessment technique may be another factor. The size of the FS was assessed in our study by calculating the field. However, the method used in the other study was to measure the maximum width (mediolateral distance) and length (ventrolateral distance) of the FS.

After puberty, FS reaches the final proportions. ${ }^{45}$ Its average volume is $10 \mathrm{cc}$, which ranges from 0 to $37 \mathrm{cc} .^{46}$ The volume of FS varies considerably in individuals of the same age. ${ }^{47}$ Moreover, the right and left frontal sinuses of the same individual can develop asymmetrically and independently. ${ }^{46} \mathrm{FS}$ might be aplastic at varying rates in different populations. ${ }^{48,49}$ This rate can reach 40 percent in some societies..$^{50}$ The patients with aplastic FS were excluded from the study in our research. However, there was a considerable variation between the minimum and maximum values of the field calculations (Table 6). We believe that this may have had an impact on the findings of the study.

Table 6. Mean values of the CEP and PA measurements. There was a considerable discrepancy between the maximum and minimum values.

\begin{tabular}{|c|c|c|c|c|c|}
\hline & & Mean & Std. Deviation & Minimum & Maximum \\
\hline \multirow{4}{*}{ CEP $\mathrm{cm}^{2}$} & Group A & 1.99 & .86 & .31 & 4.50 \\
\hline & Group B & 2.11 & .84 & .70 & 4.70 \\
\hline & Group C & 2.46 & .94 & .79 & 7.14 \\
\hline & Total & 2.17 & .89 & .31 & 7.14 \\
\hline \multirow{4}{*}{$\mathrm{PA} \mathrm{cm}^{2}$} & Group A & 8.46 & 3.57 & .37 & 16.96 \\
\hline & Group B & 8.49 & 3.20 & 1.58 & 20.12 \\
\hline & Group C & 9.83 & 3.24 & 3.06 & 22.43 \\
\hline & Total & 8.87 & 3.40 & .37 & 22.43 \\
\hline
\end{tabular}

CEP cm2: lateral cephalometric area, PA cm2: posterior-anterior area

The relationship between the size of paranasal sinuses and the types of skeletal malocclusion is controversial. Dhiman et al. reported that the frontal sinus area was larger in skeletal Class III malocclusion than in skeletal Class I and Class II. ${ }^{51}$ This is consistent with the findings of our study. However, Sabharwal et al. suggested that the frontal sinus size was independent of the type of malocclusion. $^{52}$
Frontal bone is one of the strongest structures in the face. ${ }^{53}$ Frontal bone fracture is rare because it is more resistant to mechanical forces than other maxillofacial bones. However, motor vehicle accidents, gunshot, assault or falls could cause frontal bone fractures. High-impact traumas and compressive forces deform the convexity of the front bone into concavity that significantly impairs facial aesthetics. As a consequence, the frontal bone needs to be reconstructed functionally and 
esthetically. The main goal of treatment is therefore to create a safe frontal sinus and restore the facial contour. The findings of the study could be useful for a plastic or maxillofacial surgeon who needs to reconstruct the face of a severely damaged patient.

Our research was performed without gender considerations and the FS was evaluated by 2dimensional field measurement. Additionally, due to its difficult determination in the 2D film, the frontal sinus septum was ignored in calculations. The results could have been affected by these limitations. Further studies are needed to evaluate the relation of forehead aesthetics, malocclusions, and FS with more advanced techniques and more specific and larger examples.

\section{CONCLUSIONS}

- There was a limited correlation between malocclusions, frontal sinus and forehead morphology.

- Gender was not an element that creates morphological differences in forehead aesthetics.

\section{CONFLICTS OF INTEREST STATEMENT}

The author declares no conflict of interest in this study.

\section{REFERENCES}

1. Lee Y-J, Park J-T, Cha J-Y. Perioral soft tissue evaluation of skeletal Class II Division 1: A lateral cephalometric study. Am J Orthod Dentofac Orthop 2015;148:405-413.

2. Steiner CC. The use of cephalometrics as an aid to planning and assessing orthodontic treatment. Am J Orthod 1960;46:721-735.

3. Merrifield LL. The profile line as an aid in critically evaluating facial esthetics. Am J Orthod 1966;52:804822.

4. Bishara SE, Jakobsen JR, Hession TJ, Treder JE. Soft tissue profile changes from 5 to 45 years of age. Am J Orthod Dentofac Orthop 1998;114:698-706.

5. Torlakovic L, Færøvig E. Age-related changes of the soft tissue profile from the second to the fourth decades of life. Angle Orthod 2011;81:50-57.

6. Lillie EM, Urban JE, Lynch SK, Weaver AA, Stitzel JD. Evaluation of Skull Cortical Thickness Changes With Age and Sex From Computed Tomography Scans. J Bone Miner Res 2016;31:299-307.

7. Čechová M, Dupej J, Brůžek J, Bejdová Š, Horák M,
Velemínská J. Sex estimation using external morphology of the frontal bone and frontal sinuses in a contemporary Czech population. Int J Legal Med 2019;133:1285-1294.

8. Janson G, Mendes LM, Junqueira CHZ, Garib DG. Soft-tissue changes in Class II malocclusion patients treated with extractions: a systematic review. Eur J Orthod 2016;38:631-637.

9. Kim B, Lee H-C, Kim S-H, Kim Y, Son W, Kim SS. Hard- and soft-tissue profiles of the midface region in patients with skeletal Class III malocclusion using conebeam computed tomography multiplanar-reconstructed image analysis. Korean J Orthod 2018;48:143.

10. Lam K, Ho T, Yao WC. Sinocutaneous Fistula Formation After Forehead Recontouring Surgery for Transgender Patients. J Craniofac Surg 2017;28:274277.

11. Wong JK. Forehead augmentation with alloplastic implants. Facial Plast Surg Clin North Am 2010;18:7177.

12. Maggio M Di. Forehead and Orbital Rim Remodeling. Facial Plast Surg Clin North Am 2019;27:207-220.

13. Duque CS, Casiano RR. Surgical anatomy and embryology of the frontal sinus. In: The Frontal Sinus. Springer Berlin Heidelberg 2005:21-31.

14. Schaeffer JP. The genesis, development, and adult anatomy of the nasofrontal region in man. Am J Anat 1916;20:125-146.

15. Aydinlioğlu A, Kavakli A, Erdem S. Absence of frontal sinus in Turkish individuals. Yonsei Med J 2003;44:215-218.

16. Spaeth J, Krügelstein U, Schlöndorff G. The paranasal sinuses in CT-imaging: Development from birth to age 25 . Int $\mathrm{J}$ Pediatr Otorhinolaryngol 1997;39:25-40.

17. Christensen AM. Assessing the variation in individual frontal sinus outlines. Am J Phys Anthropol 2005; 127:291-295.

18. Aslier NGY, Zeybek G, Karabay N, et al. The Relationships Between Craniofacial Structure and Frontal Sinus Morphology: Evaluation With Conventional Anthropometry and CT-Based Volumetry. Ear, Nose Throat J 2019; 29:145-156

19. Andrews WA. AP relationship of the maxillary central incisors to the forehead in adult white females. Angle Orthod 2008;78:662-669.

20. Hwang H-S, Kim W-S, McNamara JA. Ethnic 
differences in the soft tissue profile of Korean and European-American adults with normal occlusions and well-balanced faces. Angle Orthod 2002;72:72-80.

21. Guerrero-Apolo JD, Navarro-Pastor JB, BulbenaVilarrasa A, Gabarre-Mir J. The slant of the forehead as a craniofacial feature of impulsiveness. Rev Bras Psiquiatr 2018;40:270-276.

22. Theobald AH, Wong BKJ, Quick AN, Thomson WM. The impact of the popular media on cosmetic dentistry. N Z Dent J 2006;102:58-63.

23. Furnham A, Levitas J. Factors that motivate people to undergo cosmetic surgery. Can J Plast Surg 2012;20:47-50.

24. Oh MJ, Kang SJ, Jeon SP, Sun H. Forehead Inclination in the Lateral Profile in Koreans. Arch Plast Surg 2016;43:293-295.

25. Baccetti T, Reyes BC, McNamara JA. Gender differences in Class III malocclusion. Angle Orthod 2005;75:510-520.

26. Tuxen A, Bakke M, Pinholt EM. Comparative data from young men and women on masseter muscle fibres, function and facial morphology. Arch Oral Biol 1999;44:509-517.

27. Alvesalo L. Human sex chromosomes in oral and craniofacial growth. Arch Oral Biol 2009;54:18-24.

28. Olsen JA, Inglehart MR. Malocclusions and perceptions of attractiveness, intelligence, and personality, and behavioral intentions. Am J Orthod Dentofac Orthop 2011;140:669-679.

29. Urban JE, Weaver AA, Lillie EM, Maldjian JA, Whitlow CT, Stitzel JD. Evaluation of morphological changes in the adult skull with age and sex. J Anat 2016;229:838-846.

30. Lee S-Y, Lee J-W, Cha K-S, Jung D-H, Lee S-M. An Evaluative Study on Forehead Morphology of Individuals with Normal Occlusion and Position of Maxillary Incisor in Accordance to Forehead Morphology. J Dent Rehabil Appl Sci 2013;29:236-248. 31. D'Onofrio L. Oral dysfunction as a cause of malocclusion. Orthod Craniofac Res 2019;22:43-48.

32. Grippaudo C, Paolantonio EG, Antonini G, Saulle R, La Torre G, Deli R. Association between oral habits, mouth breathing and malocclusion. Acta Otorhinolaryngol Ital 2016;36:386-394.

33. Linder-Aronson S. Respiratory Function in Relation to Facial Morphology and the Dentition Br J Orthod 1979;6:59-71.

34. Assis NIL, Seixas MF d. S, Mendes TÂDS, et al.
Retrospective study of morphological and functional alterations in patients with long face syndrome diagnosis. Int J Oral Maxillofac Surg 2019;48:188-294. 35. Cha K-S. Soft-tissue thickness of South Korean adults with normal facial profiles. Korean J Orthod 2013;43:178-185.

36. Hwang H-S, Park M-K, Lee W-J, Cho J-H, Kim B$\mathrm{K}$, Wilkinson CM. Facial Soft Tissue Thickness Database for Craniofacial Reconstruction in Korean Adults. J Forensic Sci 2012;57:1442-1447.

37. Kamak H, Celikoglu M. Facial soft tissue thickness among skeletal malocclusions: is there a difference? Korean J Orthod 2012;42:23-31.

38. Hixon EH. The norm concept and cephalometrics. Am J Orthod 1956;42:898-906.

39. Celebi AA, Tan E, Gelgor IE, Colak T, Ayyildiz E. Comparison of soft tissue cephalometric norms between Turkish and European-American adults. Sci Worl J 2013;2013:806203.

40. Samizadeh S. The Ideals of Facial Beauty Among Chinese Aesthetic Practitioners: Results from a Large National Survey. Aesthetic Plast Surg 2019;43:102-114. 41. Mehl C, Wolfart S, Vollrath O, Wenz H-J, Kern M. Perception of Dental Esthetics in Different Cultures. Int J Prosthodont 2014;27:523-529.

42. Sassouni V. A classification of skeletal facial types. Am J Orthod 1969;55:109-123.

43. Bittner C, Pancherz H. Facial morphology and malocclusions. Am J Orthod Dentofac Orthop 1990;97:308-315.

44. Adibelli ZH, Songu M, Adibelli H. Paranasal sinus development in children: A magnetic resonance imaging analysis. Am J Rhinol Allergy 2011;25:30-35.

45. Manolidis S, Hollier LH. Management of frontal sinus fractures. Plast Reconstr Surg 2007;120:32-48.

46. Levine HL CM. In: Clemente MP, ed. Surgical Anatomy of the Paranasal Sinus. In: Sinus Surgery: Endoscopic and Mi-Croscopic Approaches 2003; 1-55.

47. Fatu C, Puisoru M, Rotaru M, Truta AM. Morphometric evaluation of the frontal sinus in relation to age. Ann Anat 2006;188:275-280.

48. Çakur B, Sumbullu MA, Durna NB. Aplasia and agenesis of the frontal sinus in Turkish individuals: a retrospective study using dental volumetric tomography. Int J Med Sci 2011;8:278-282.

49. Pondé JM, Metzger P, Amaral G, Machado M, Prandini M. Anatomic variations of the frontal sinus. Minim Invasive Neurosurg 2003;46:29-32. 
50. Koertvelyessy T. Relationships between the frontal sinus and climatic conditions: A skeletal approach to cold adaptation. Am J Phys Anthropol 1972;37:161172.

51. Dhiman I, Singla A, Mahajan V, Jaj HS, Seth V, Negi P. Reliability of frontal sinus with that of maxillary sinus in assessment of different types of skeletal malocclusions. J Indian Orthod Soc 2015;49:96-103.
52. Sabharwal A, Patil A, Shinde S, Swami V. Analysis of frontal sinus in various malocclusions. Int $\mathrm{J}$ Orthod Rehabil 2019;10:116-121.

53. Dickinson JT, Cipcic JA, Kamerer DB. Principles of frontal reconstruction. Laryngoscope 1969;79:10191075 . 